九州大学学術情報リポジトリ

Kyushu University Institutional Repository

\title{
On the Estimation of Oxygen Partial Pressure Associated with Lava
}

Shinno, Isamu

Department of General Education, Kyushu University

https://doi.org/10.5109/1543677

出版情報：九州大學理學部紀要：Series D, Geology. 18 (2)，pp.367-377，1967-12-25. Faculty of Science, Kyushu University バージョン：

権利関係 : 
Mem. Fac. Sci., Kyushu Univ., Ser. D, Geology, Vol. XVIII, No. 2, pp. 367-377, text-figs. 1-5, tables 1-3, Dec. 25, 1967

\title{
On the Estimation of Oxygen Partial Pressure Associated with Lava
}

By

\author{
Isamu SHINNO
}

\begin{abstract}
In this paper the method of estimation of partial oxygen pressure $\left(\mathrm{Po}_{2}\right)$ associated with lave is reconsidered on the thermodynamic bases, and some results of experiment to know how $\mathrm{Na}$ ion in lave has an effect on the $\mathrm{Fe}^{+3}$ $\mathrm{Fe}^{+2}-\mathrm{O}^{-2}$ equilibrium are reported.

It is explicit that each lava has its own equilibrium constant of iron redex reactions. $\mathrm{Fe}^{+3}$ is more stable than $\mathrm{Fe}^{+2}$ with rising temperature in sodium glass and alkalirhyolite at air atmosphere. This is opposite to normal state which $\mathrm{Fe}^{+2}$ is more stable than $\mathrm{Fe}^{+3}$ with rising temperature.

Besides, the geologic " $\mathrm{Po}_{2}$-barometer" of olivine and pyroxene is discussed to estimate the oxygen partial pressure associated with lava.
\end{abstract}

\section{Introduction}

Some experimental petrologists have recognized that the oxygen partial pressure is one of the most important factors to be discussed for the petrogenetic investigation of igneous rock. Distinguishable effects of $\mathrm{Po}_{2}$ may be reflected on the ratio of ferric to ferrous iron of lava.

In 1948 G. C. KENNEDY was the first that treated experimentally a lava as an ideal solution of ferric-ferrous iron ions (KENNEDY, 1955). He applied the equilibrium constant of ferric-ferrous iron ions and oxygen ion obtained at each constant temperature in air to a lava, and estimated that $\mathrm{Po}_{2}$ may be $10^{-8}-10^{-5}$ atms at $1000-1400^{\circ} \mathrm{C}$ in magma. This report is famous for "Fenner trend" and "Bowen trend" as the first proposal of the significance of atmosphere for the differentiation of magma.

OsBoRN (1959-62) had evolved petrogenetic discussion based on the MgO$\mathrm{FeO}-\mathrm{Fe}_{2} \mathrm{O}_{3}-\mathrm{SiO}_{2}$ system studied by MUAN and OsBonN (1956) at controlled $\mathrm{Po}_{2}$ atmosphere. Although natural lavas are not so simple as explainable by the "simple basalt system", the genetic relations among calcalkaline, hypersthenic, pigeonitic and alkaline rock series in orogenic belt are explained by the relation of $\mathrm{Po}_{2}$ in the magmas (KUNO, 1965; TANEDA, 1966).

TANEDA (1966) concluded that alkalic rock magmas are produced and crystallized at comparatively high vapor pressure $\left(\mathrm{PH}_{2} \mathrm{O}, \mathrm{Po}_{2}\right.$, etc. $)$ and low temperature,

Manuscript received September 16, 1967.

Isamu SHINno: Department of General Education, Kyushu University. 
while nonalkalic (tholeiitic, calcalkalic) rock magmas at low vapor pressure and high temperature. FUdALI (1965) has experimentally determined $\mathrm{Po}_{2}$ equilibrating with the original ratio of ferrous to ferric iron in a natural lavas at $1200^{\circ} \mathrm{C}$.

I have reexamined fundamentally the thermodynamic method for estimation of $\mathrm{Po}_{2}$ used by KENNEDY (1948) and FudALI (1965), and on the other hand, obtained experimentally some data of the stability of ferric, ferrous iron and oxygen ions in a lava which are affected by coexisting $\mathrm{Na}$ ion at different atmosphere such as $\mathrm{CO}_{2} / \mathrm{H}_{2}$ gas mixture or air. In this paper new method to estimate $\mathrm{Po}_{2}$ associated with a lava, geologic $\mathrm{Po}_{2}$-barometer by means of olivine and pyroxene redox reactions, is also discussed.

\section{Acknowledgements}

I thank Assist. Prof. S. TANEDA who gave me the important suggestion and opportunity to experiment, and had a critical read of the manuscript. Also I wish to express my thanks to Dr. H. MoMoI for his suggestion on experimental method and to K. IsHIBASHI for an offer of analyzed alkalirhyolite.

\section{Estimation of $\mathrm{Po}_{2}$ based on Equilibrium Relation of Iron-Oxygen in a Lava}

Assuming that a lava is a dilute solution of a divalent and trivalent iron ions, we can consider the following reaction.

$$
2 \mathrm{Fe}^{+3}+\mathrm{O}^{-2}=2 \mathrm{Fe}^{+2}+1 / 2 \mathrm{O}_{2}
$$

This ionic reaction (1) may be suitable for a lava of high temperature. We can, however, not measure electromotive forces of (1) in silicate melt at high temperature. We may be able to examine the following reaction (2) through quenching method.

$$
2 \mathrm{Fe}_{2} \mathrm{O}_{3}=4 \mathrm{FeO}+\mathrm{O}_{2}
$$

FUDALI (1965), however, has suggested that the next equation would be more suitable for iron-oxygen equilibrium reaction.

$$
4 \mathrm{FeO}_{1.5}=4 \mathrm{FeO}+\mathrm{O}_{2}
$$

Here we discuss mainly about the reaction (3) on the basis of thermodynamic theories. Equilibrium constant of the reaction (3) at constant temperature should be

$$
\mathrm{Kpo}_{2}=\frac{(\mathrm{FeO} \mathrm{mol} \%)^{4}}{\left(\mathrm{FeO}_{1.5} \mathrm{~mol}_{\%}\right)^{4}} \mathrm{Po}_{2}
$$

Activities of the ion in melt is assumed to be in accordance with each mol fraction and not affected by confining pressure.

There are two methods to estimate $\mathrm{Po}_{2}$ in a lava from the equilibrium con- 
stant which are a function of oxidation index (O.I.), $\mathrm{Po}_{2}$ and temperature (T). Here the "Oxidation index" is defined as follows;

$$
\text { O.I. }=\frac{\mathrm{FeO} \mathrm{mol} \%}{\mathrm{FeO}_{1.5} \mathrm{~mol} \%}
$$

\section{A. KENNEDY's Method}

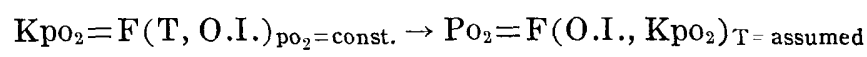

Based on this formula, he calculated $\mathrm{Po}_{2}$ in a lava from $\mathrm{Kpo}_{2}$ obtained as a function of T, O.I. at constant $\mathrm{Po}_{2}$ (air). In this case, temperature of lava is assumed by preferable value.

\section{B. Fudali's Method}

It is characteristic of deciding $1200^{\circ} \mathrm{C}$ as temperature of lava and so the changes of O.I. depend on merely $\mathrm{Po}_{2}$ or vice versa as represented by the following equation.

$$
\mathrm{Kpo}_{2}=\mathrm{F}\left(\mathrm{Po}_{2}, \text { O.I. }\right)_{\mathrm{T}=\text { assumed }} \rightarrow \mathrm{Po}_{2}=\mathrm{F}(\text { O.I. })_{\mathrm{Kpo}_{2}=\text { const. }}
$$

By the equations (4) and (5),

$$
1 / 4 \log \mathrm{Po}_{2}=-\log \text {. O.I. }+1 / 4 \log \mathrm{Kpo}_{2}
$$

We can get $\mathrm{Po}_{2}$ from equation (8) by means of equilibrating a given lava sample at different controlled $\mathrm{Po}_{2}$ until the original $\mathrm{FeO} / \mathrm{FeO}_{1.5}$ ratio of lava is maintained.

Here the $\mathrm{Po}_{2}$ is estimated by two methods above mentioned on a number of

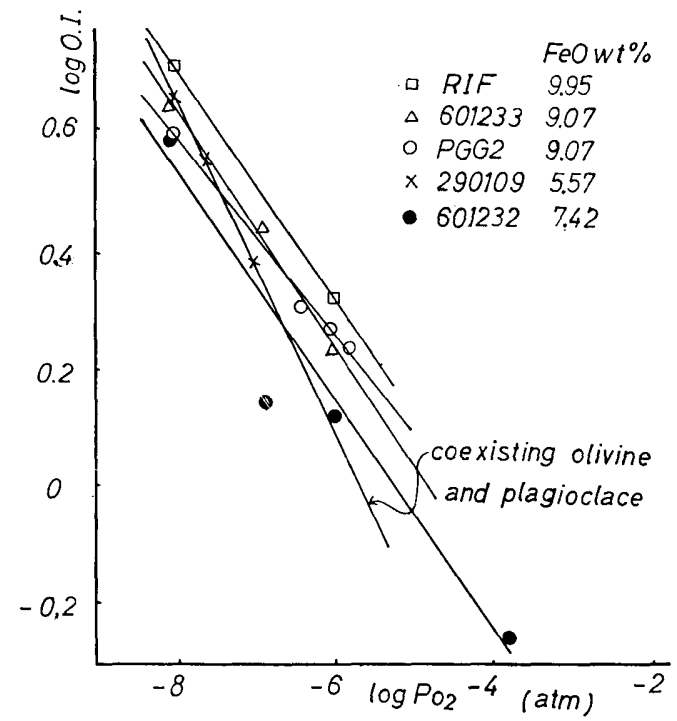

Fig. 1. Relations between oxidation index and oxygen partial pressure in a lava based on the equation (8). Each lave has its own $\mathrm{Kpo}_{2}$ which is proportionally FeO wt\% (R.F. FudALI 1965). 
assumptions. To know the exact temperature of lava is impossible by any geologic thermometer. TILLEY and YODER (1962) reported on the basis of their experiments of basaltic rock melt that crystallization range and appearance of major silicate phases occurred in a comparative narrow temperature interval. It may be possible to calculate within the limits of error $\pm 100^{\circ} \mathrm{C}$ for basaltic rock.

Each lava has its own peculiar $\mathrm{Kpo}_{2}$ which is proportionally $\mathrm{FeO}$ wt\% (FudALI, 1965). This is non ideal solution because iron ion may be affected by other coexisting ions.

Then equilibrium constant $\mathrm{Kpo}_{2}$ is not applied to all lavas just as KENNEDY has done. If we dare to estimate $\mathrm{Po}_{2}$ in the face of danger of assuming a particular temperature of lava, we have to solve the equation (8) for each lava.

290109 (FUDALI, 1965) containing olivine and plagioclace has more steep gradient than complete glass (Fig. 1). This fact is a difficult problem for a lava mostly containing some crystal or microlites. Besides, $\mathrm{Po}_{2}$ in magma may be variable in the course of crystallization. To what stage of crystallization does the experimentally obtained $\mathrm{Po}_{2}$ correspond?

\section{Equilibrium Relation of Iron-Oxygen in a Lava}

On the grounds of discussions in the preceding section, it has become clear that $\mathrm{Kpo}_{2}$ obtained from one specimen is not applied to all lavas. Conversely speaking the stability of iron-oxygen is different in each lava which is various in chemical composition and physical conditions.

Now in this section we shall discuss Gibb's energy change of the reaction (3) in a lava and of a reaction (2) in pure oxide. From equation (4),

Then

$$
\mathrm{Kpo}_{2}=\exp -\Delta \mathrm{G} / \mathrm{RT}
$$

$$
\Delta \mathrm{G}=-\mathrm{RT} \ln \mathrm{Kpo}_{2}
$$

Data for stability relation between iron and oxygen in a alkali-rhyolite melt and in a tholeiitic basalt melt at air or $\mathrm{CO}_{2} / \mathrm{H}_{2}$ gas mixture atmosphere are presented in table 1. This alkali-rhyolite contains mainly alkali feldspar and a little of pigeonite and riebeckite. The chemical compositions are also presented in table 1. Experimental method of alkali-rhyolite performed by the writer is similar to Fudali's Method (1965). Calculation of $\mathrm{Po}_{2}$ was done by dissociation constant of reaction $2 \mathrm{CO}_{2}=2 \mathrm{CO}+\mathrm{O}_{2}$ and $\mathrm{CO}_{2}+\mathrm{H}_{2}=\mathrm{CO}+\mathrm{H}_{2} \mathrm{O}$ listed in OsBoRN and MuAN's paper (1956). For preventing from iron loss to container, Ag-Pd $(60: 40)$ arroy container was used, but conical Pt-Rh $(80: 20)$ crucible was used above $1200^{\circ} \mathrm{C}$. In table 2 , the same data about sodium glass (T. BAAK and HORNYAK 1961) and pure iron oxide calculated from CoughLIN's table (1954) are presented for comparison. Fig. 2 shows the relation among $\Delta \mathrm{G}, \mathrm{T}$ and $\log$ $\mathrm{Po}_{2}$ based on table (1)-(2), but we conveniently consider that $\mathrm{Fe}^{+2}$ oxidize to $\mathrm{Fe}^{+3}$ as represented $4 \mathrm{FeO}+\mathrm{O}_{2}=4 \mathrm{FeO}_{1.5}$. In Fig. $2 \Delta \mathrm{G}$ calculated from the reaction (2) for the lava more deviate from the $\Delta G$ of pure oxide comparing with $\Delta G$ calculated from the reaction (3). Consequently the stability relation of iron 
Table 1. The iron-oxygen equilibrium in silicate melt

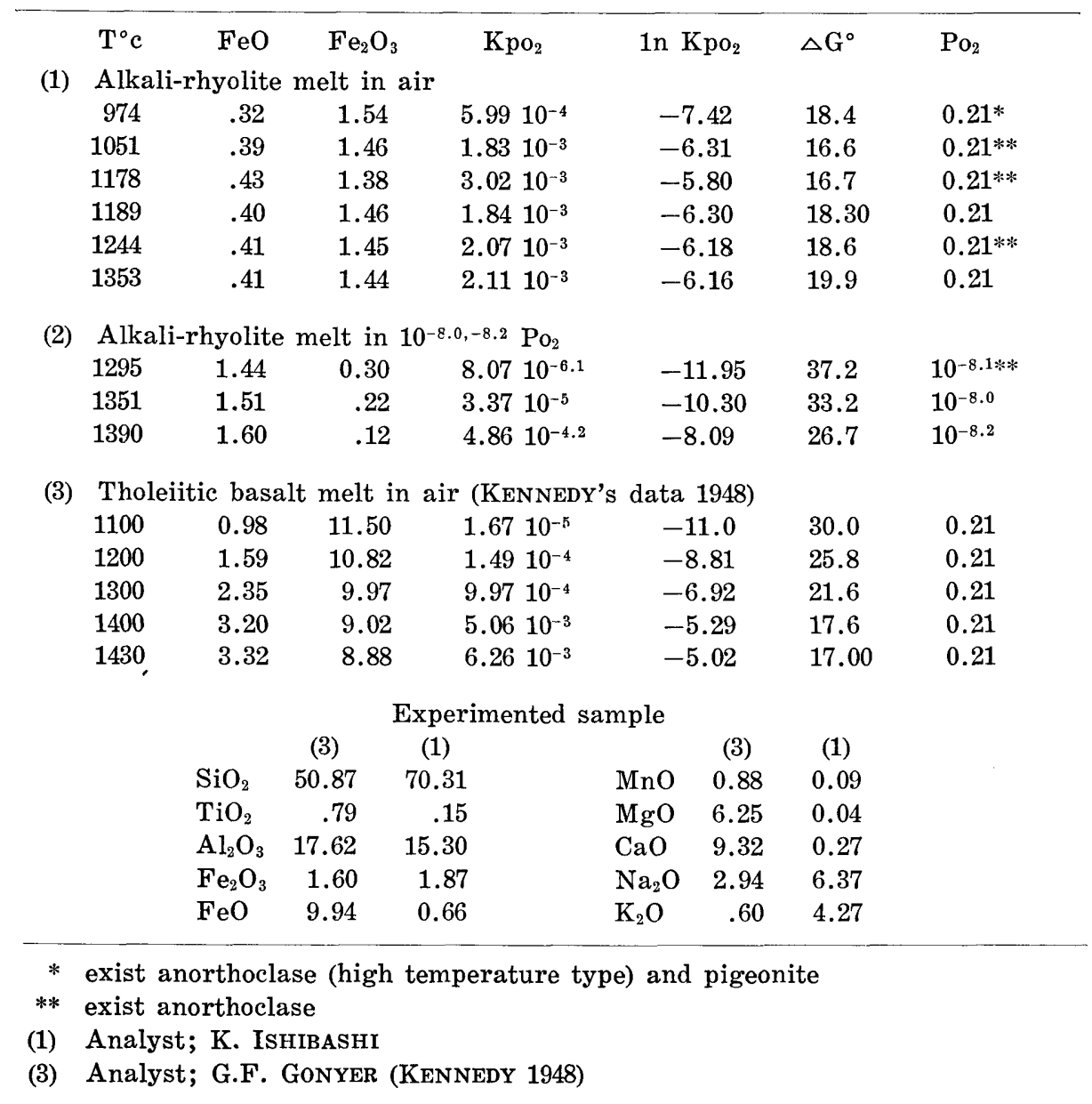

oxide in a lava may be actually represented in reaction (3). This is in accordance with FUDALI's idea that reaction (3) is a much closer approximation to reality.

Most distinguishable facts in Fig. 2 are alkali-rhyolite melt and sodium glass having opposite gradient. The Gibbs energies of reaction (3) increase with rising temperature just in opposite to the free energies for the pure oxide. At another view point, increasing $\Delta G$ of pure oxide with rising temperature shows that reaction (3) proceeds spontaneously to the higher reduction state even at constant atmosphere, but in the cases of alkali-rhyolite and sodium glass it is just opposite.

Associating with special high activity energies of sodium in volcanic glass studied by KIRIYAMA (1965) by means of dielectric loss, this abnormal phenomenon may be caused by high contents of sodium ion in alkali-rhyolite and sodium glass. This fact is important to be applied to a lava. We can not say explicitly that in general those lavas with low O. I. show a high oxidation state. Stability of acmite $\left(\mathrm{NaFe}^{+3}\right) \mathrm{SiO}_{3}$ contained in alkali rock may be explained not only by 
Table 2. The iron-oxygen equilibrium in silicate melt

\begin{tabular}{|c|c|c|c|c|c|c|c|}
\hline & $\mathrm{T}^{\circ} \mathrm{c}$ & $\mathrm{FeO}$ & $\mathrm{Fe}_{2} \mathrm{O}_{3}$ & $\mathrm{Kpo}_{2}$ & 1n $\mathrm{Kpo}_{2}$ & $\Delta \mathrm{G}^{\circ}$ & $\mathrm{Po}_{2}$ \\
\hline \multirow[t]{17}{*}{ (4) } & \multicolumn{7}{|c|}{$\mathrm{Na}_{2} \mathrm{SiO}_{4}$ glass in air. (T. BAAK and E.J. HORNYAK, 1961) } \\
\hline & 1200 & 0.179 & 4.71 & $6.7710^{-7}$ & -14.2 & 41.6 & 0.21 \\
\hline & 1100 & .157 & 4.74 & 3.87 & -14.8 & 40.3 & 0.21 \\
\hline & 1000 & .143 & 4.75 & 2.62 & -15.2 & 38.3 & 0.21 \\
\hline & 900 & .137 & 4.76 & 2.17 & -15.3 & 35.8 & 0.21 \\
\hline & 1200 & .100 & 2.82 & 5.01 & -14.5 & 42.5 & 0.21 \\
\hline & 1100 & .088 & 2.84 & 2.94 & -15.0 & 41.0 & 0.21 \\
\hline & 1000 & .078 & 2.84 & 1.83 & -15.5 & 39.2 & 0.21 \\
\hline & 900 & .074 & 2.85 & 1.45 & -15.8 & 36.7 & 0.21 \\
\hline & 1200 & .034 & .94 & 5.58 & -14.4 & 42.2 & 0.21 \\
\hline & 1100 & .031 & .94 & 3.95 & -14.7 & 40.2 & 0.21 \\
\hline & 1000 & .029 & .94 & 2.98 & -15.0 & 38.0 & 0.21 \\
\hline & 900 & .028 & .94 & 2.44 & -15.2 & 35.5 & 0.21 \\
\hline & 1200 & .005 & .097 & $2.3110^{-6}$ & -13.0 & 38.0 & 0.21 \\
\hline & 1100 & .005 & .097 & 2.31 & -13.0 & 38.0 & 0.21 \\
\hline & 1000 & .004 & .098 & $9.0810^{-7}$ & -13.9 & 35.2 & 0.21 \\
\hline & 900 & .004 & .098 & 9.08 & -13.9 & 35.2 & 0.21 \\
\hline \multirow[t]{4}{*}{ (5) } & \multicolumn{7}{|c|}{ Pure oxide (calculated from specific heat capacity) } \\
\hline & 1400 & & & $6.1410^{-6}$ & -12.0 & 40.0 & \\
\hline & 1200 & & & $2.5110^{-8}$ & -17.5 & 51.3 & \\
\hline & 1000 & & & $1.6910^{-11}$ & -24.8 & 62.7 & \\
\hline
\end{tabular}

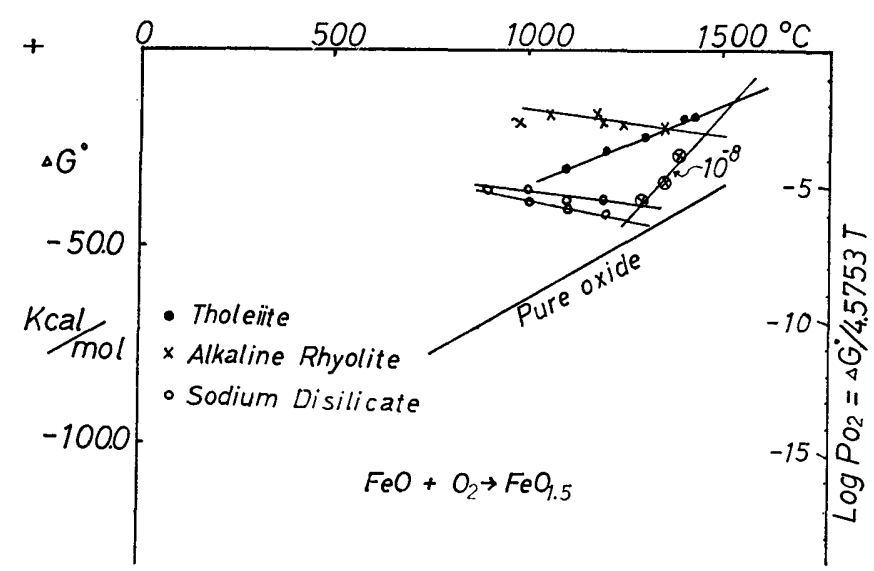

Fig. 2. Relations between stability and oxygen partial pressure in equilibrium with iron ion in a lave. Contrary to pure oxide, $\mathrm{Fe}^{+3}$ in soda-glass and alkali rhyolite is more stable than $\mathrm{Fe}^{+2}$ with rising temmperature.

high oxygen partial pressure (YAGI, 1966) associated with a lava but also by what $\mathrm{Fe}^{+3}$ is more stable than $\mathrm{Fe}^{+2}$ at rising temperature. But alkali-rhyolite melt at ${ }^{10-8} \mathrm{Po}_{2}$ has not the same $\mathrm{KPo}_{2}$ as obtained in air as represented in Fig. 2 . This fact should be explained by further study. 


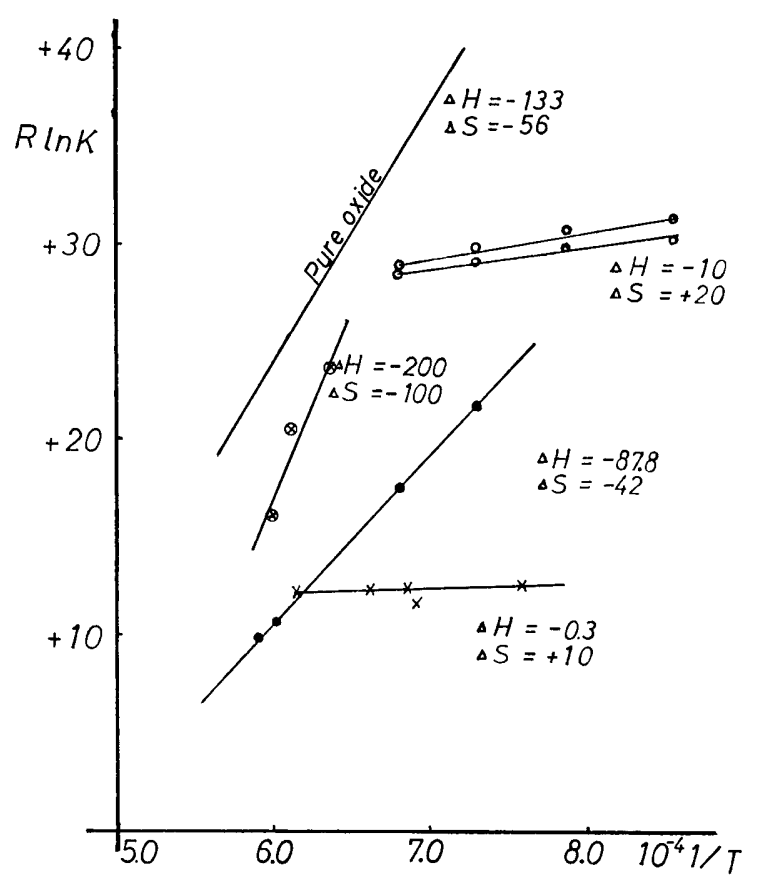

Fig. 3. Thermodynamic properties of the iron-oxygen equilibrium in a lava. $\mathrm{Na}^{+}$coexisting with iron is effective to decrease a entropy and heat content changes of reaction $4 \mathrm{FeO}+\mathrm{O}_{2}=4 \mathrm{FeO}_{1.5}$. Symboles are same to Fig. 2.

Now we consider the following equation converted from equation (10);

$$
\mathrm{R} 1 \mathrm{n} \mathrm{Kpo}_{2}=\Delta \mathrm{S}-\Delta \mathrm{H} 1 / \mathrm{T}
$$

Thermodynamic properties of iron-oxygen redox reaction in a lava are presented in Fig. 3 on the basis of equation (11). Entropy and entalpy changes of redox reaction in alkali-rhyolite and sodium glass at air atmosphere are very different from others. It is characteristic that the heat of oxidation is small and entropy of ferric iron is large.

\section{"Geologic $\mathrm{Po}_{2}$-Barometer" of Olivine and Pyroxene}

Most lavas contain olivine and pyroxene which are closely associated with magnetite rims or exsolution lamellae and others (KUNO, 1950 ; TANEDA, 1943, 47, 52 ; Shinno, 1966; etc.). These phenomena caused by oxidation are applied to estimate $\mathrm{Po}_{2}$ in lava. Now we have to calculate that how $\mathrm{Fe}_{2} \mathrm{SiO}_{4}, \mathrm{FeSiO}_{3}$ end members of olivine and pyroxene resist to oxygen atmosphere. Next redox reaction of $\mathrm{Fe}_{2} \mathrm{SiO}_{4}, \mathrm{FeSiO}_{3}$ may be considered simply.

$$
\begin{aligned}
& 6 \mathrm{Fe}_{2} \mathrm{SiO}_{4}+\mathrm{O}_{2}=2 \mathrm{Fe}_{3} \mathrm{O}_{4}+6 \mathrm{FeSiO}_{3} \\
& 4 \mathrm{Fe}_{2} \mathrm{SiO}_{4}+\mathrm{O}_{2}=2 \mathrm{Fe}_{3} \mathrm{O}_{4}+2 \mathrm{FeSiO}_{3}+2 \mathrm{SiO}_{2}
\end{aligned}
$$




$$
\begin{aligned}
& 3 \mathrm{Fe}_{2} \mathrm{SiO}_{4}+\mathrm{O}_{2}=2 \mathrm{Fe}_{3} \mathrm{O}_{4}+3 \mathrm{SiO}_{2} \\
& 6 \mathrm{FeSiO}_{3}+\mathrm{O}_{2}=2 \mathrm{Fe}_{3} \mathrm{O}_{4}+6 \mathrm{SiO}_{2} \\
& 3 / 2 \mathrm{Fe}_{2} \mathrm{SiO}_{4}+3 \mathrm{FeSiO}_{3}+\mathrm{O}_{2}=4 \mathrm{Fe}_{3} \mathrm{O}_{4}+9 \mathrm{SiO}_{2}
\end{aligned}
$$

Thermodynamic data for calculation are obtained from KELLEY (1960) and

\begin{tabular}{|c|c|c|c|c|c|c|}
\hline Mineral & $\Delta \mathrm{H}^{\circ} 298$ & $\Delta \mathrm{S}^{\circ} 298$ & $a_{0} *$ & $a_{1} *$ & $a_{2} *$ & $\mathrm{~T}^{\circ} \mathrm{K}$ range \\
\hline $\mathrm{Fe}_{2} \mathrm{SiO}^{4}$ & -346 & 34.7 & 36.51 & 9.36 & -6.70 & $298-1490$ \\
\hline $\mathrm{FeSiO}_{3} * *$ & -279 & 21 & 25 & 5.2 & -3 & $523-1490$ \\
\hline $\mathrm{Mg}_{2} \mathrm{SiO}_{4}$ & -508.2 & 22.75 & 35.81 & 6.54 & -8.52 & $298-1800$ \\
\hline $\mathrm{MgSiO}_{3}$ & -357.9 & 16.2 & 24.55 & 4.74 & -6.28 & $298-1600$ \\
\hline $\mathrm{Fe}_{0.947} \mathrm{O}$ & -63.8 & 13.74 & 11.66 & 2.00 & -0.67 & $298-1650$ \\
\hline $\mathrm{Fe}_{2} \mathrm{O}_{3}$ & -196.5 & 21.5 & 31.71 & 1.76 & & $1050-1800$ \\
\hline $\mathrm{Fe}_{3} \mathrm{O}_{4}$ & -267.0 & 35.0 & 48.00 & & & $900-1800$ \\
\hline $\mathrm{SiO}_{2}$ **** & -205.0 & 10.2 & 14.40 & 2.04 & & 523-2000 \\
\hline $\mathrm{O}_{2}$ & 0.0 & 49.01 & 7.16 & 1.00 & -0.40 & $298-3000$ \\
\hline
\end{tabular}
Coughlin (1954). But the data of $\mathrm{FeSiO}_{3}$ were estimated by usual method

Table 3. Thermodynamic constant used in this paper.

* $\mathrm{Cp}=\mathrm{a}_{0}+\mathrm{a}_{1} 10^{-3} \mathrm{~T}+\mathrm{a}_{2} 10^{5} \mathrm{~T}^{-2}$

** estimated value, H: Hess Law; S: LAtimeR's Method;

Cp: Sahama and Torgson's Method.

*** $\beta$-cristobalite $\mathrm{H}=\mathrm{kcal} / \mathrm{mol}, \mathrm{S}=\mathrm{cal} / \mathrm{mol}$

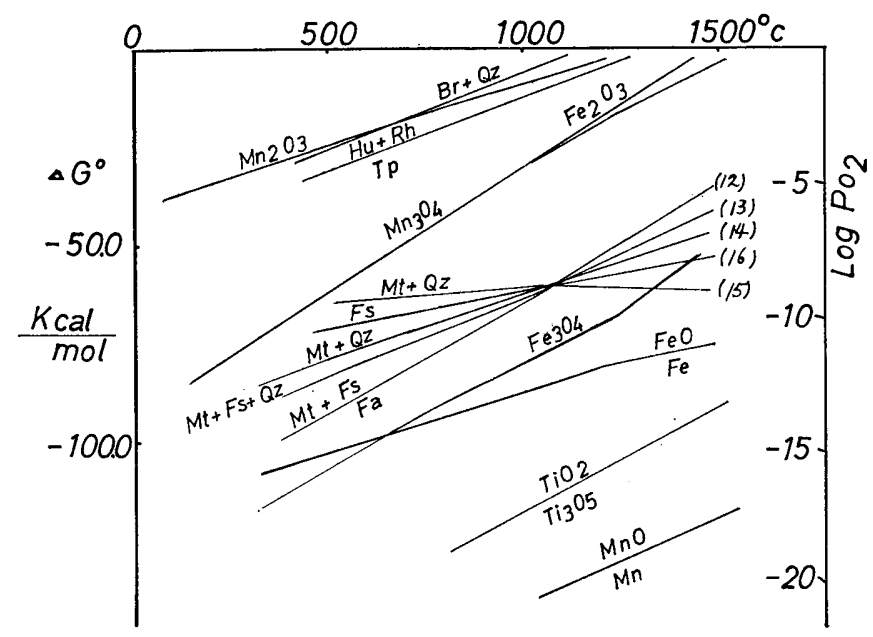

Fig. 4. Relations between staibility and $\mathrm{Po}_{2}$ in equilibrium with some metal oxides and silicates. $\mathrm{Fe}^{+2}$ and $\mathrm{Mn}^{+2}$ screened by ortho or meta-silicate persist to more higher $\mathrm{Po}_{2}$ than $\mathrm{Fe}$ and $\mathrm{Mn}$-oxide. $\mathrm{Fe}_{2} \mathrm{SiO}_{4}$ is more stable than $\mathrm{FeSiO}_{3}$ at high temperature, but the relation is reverse at low temperature. Abbreviations have the following meanings: $\mathrm{Br}=$ braunite; $\mathrm{Qz}=$ tridymite; $\mathrm{Rh}=$ rhodonite; $\mathrm{Tp}=$ tephroite; $\mathrm{Hu}=$ hausmannite; $\mathrm{Mt}=$ magnetite; $\mathrm{Fs}=$ ferrosilite; $\mathrm{Fa}=$ fayalite. (10)-(14) correspond to each reaction in the text. 
and checked by extrapolation of BOWEN and SCHAIRER's experiments (1935) (Table 3).

The above result was shown in Fig. 4 in comparison with other data, related oxide and manganese silicate (MUAN 1959). Stability of $\mathrm{Fe}_{2} \mathrm{SiO}_{4}$ and $\mathrm{FeSiO}_{3}$ is much affected by temperature and $\mathrm{Po}_{2} . \quad \mathrm{FeSiO}_{3}$ is more stable than $\mathrm{Fe}_{2} \mathrm{SiO}_{4}$ at a low temperature just as same as $\mathrm{Mn}$-silicate. $\mathrm{Fe}^{+2}$ and $\mathrm{Mn}^{+2}$ screened by silicate more strongly persist in $\mathrm{Po}_{2}$ than each oxide as illustrated in Fig. 4. Particularly $\mathrm{Mn}^{+2}$ has wider stability fields than $\mathrm{Fe}^{+2}$ and accepts much greater stabilizing effect of $\mathrm{SiO}_{2}$ in comparison with $\mathrm{Fe}^{+2}$ as already discussed by MUAN (1957). Assuming that olivines and pyroxenes form ideal solid solution respectively, the chemical potential of $\mathrm{Fe}_{2} \mathrm{SiO}_{4}$ and $\mathrm{FeSiO}_{3}$ is written by following representation.

$$
\begin{aligned}
& \mathrm{G}_{\mathrm{Fa}}=\mathrm{G}_{\mathrm{Fa}}^{0}+\mathrm{RT} \ln \mathrm{X}_{\mathrm{Fa}} \\
& \mathrm{G}_{\mathrm{Fs}}=\mathrm{G}_{\mathrm{Fs}}^{0}+\mathrm{RT} \operatorname{1n} \mathrm{X}_{\mathrm{Fs}}
\end{aligned}
$$

$\mathrm{G}_{\mathrm{Fa}}^{0}$ : Chemical potential of fayalite molecule $\left(\mathrm{Fe}_{2} \mathrm{SiO}_{4}\right)$ at pure state.

$\mathrm{G}_{\mathrm{Fs}}^{0}$ : Chemical potential of ferrosilite molecule $\left(\mathrm{FeSiO}_{3}\right)$ at pure state.

$\mathrm{X}_{\mathrm{Fa}}$ : mol. fraction of fayalite.

$\mathrm{X}_{\mathrm{Fs}}$ : mol. fraction of ferrosilite.

Then we can obtain the relation between $\mathrm{Fe}_{2} \mathrm{SiO}_{4}, \mathrm{FeSiO}_{3}$ mol fraction and its equilibrium partial oxygen pressure $\left(\log \mathrm{Po}_{2}\right)$. From above reaction (12), (13), (14), (15) and (16),

$$
\begin{aligned}
& \log \mathrm{Po}_{2} \mathrm{X}_{\mathrm{Fa}}^{6} \mathrm{X}_{\mathrm{Fs}}^{-6}=-\Delta \mathrm{G} / 2.307 \mathrm{RT} \\
& \log \mathrm{Po}_{2} \mathrm{X}_{\mathrm{Fa}}^{4} \mathrm{X}_{\mathrm{Fs}}^{-2}=-\Delta \mathrm{G} / 2.307 \mathrm{RT} \\
& \log \mathrm{Po}_{2} \mathrm{X}_{\mathrm{Fa}}^{3}=-\Delta \mathrm{G} / 2.307 \mathrm{RT} \\
& \log \mathrm{Po}_{2} \mathrm{X}_{\mathrm{Fs}}^{6}=-\Delta \mathrm{G} / 2.307 \mathrm{RT} \\
& \log \mathrm{Po}_{2} \mathrm{X}_{\mathrm{Fa}}^{3 / 2} \mathrm{X}_{\mathrm{Fs}}^{3}=-\Delta \mathrm{G} / 2.307 \mathrm{RT}
\end{aligned}
$$

In Fig. 5 the equilibrium relation based on equations (21) and (22) at constant temperature is shown graphically. If we would attempt to estimate $\mathrm{Po}_{2}$ associated with a lava based on this relation, we should know both of the crystallizing temperature and mol fraction of olivine or pyroxene in a lava, because the $\mathrm{Po}_{2}$ is independent of temperature and mol fraction. Although mol fraction of olivine or pyroxene is easily taken by X-ray method or optical method or chemical analyses as far as separation of olivine and pyroxene is done, crystallizing temperature from magma of these minerals is not easily obtained as mention in the preceding section.

In equations (19), (20) and (23) the relation of coexisting olivine and pyroxene at constant or optional temperature which is equilibrium at each $\mathrm{Po}_{2}$ is shown. The stability relation of these minerals is controlled by the reaction relation of olivine and pyroxene.

Now as distribution function of $(\mathrm{Mg}, \mathrm{Fe})$ to olivine and pyroxene in lava is not clarified, we fall into difficulty just as the crystallizing temperature is hard 


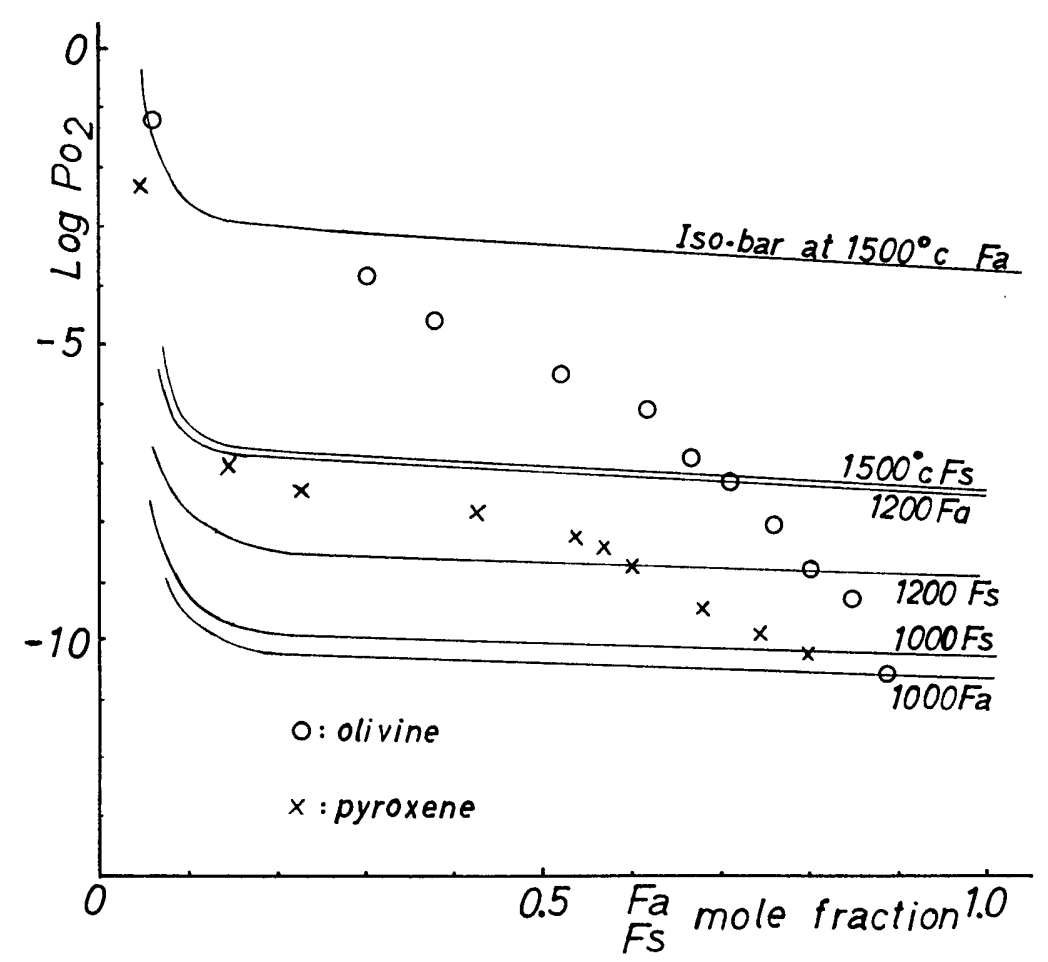

Fig. 5. Theoretical $\mathrm{Po}_{2}$ equilibrating with olivine and pyroxene based on the equation (14), (15). Calculations are preformed by thermodynamic constant in Table 3. Maximum crystallizing temperature of these minerals is quoted from $\mathrm{MgO}-\mathrm{SiO}_{2}-\mathrm{FeO}$ ternary system studied by BowEN et al. (1935). But crystallizing temperature of these minerals may be lowered in lave.

to be exactly estimated. These problem may be discussed in more detailed in another paper.

\section{Summary}

The possibilities estimating of $\mathrm{Po}_{2}$ in a lava were discussed by two ways. One is the application of $\mathrm{Fe}^{+3}-\mathrm{Fe}^{+2}-\mathrm{O}^{-2}$ equilibrium relation which may occurred at high temperature. In this case I have discussed about KENNEDY's method and FUDALI's method which are discriminated from each other by the relation between $\mathrm{Kpo}_{2}$, T and O.I. just as the equations (6) and (7). Consequently it is explicit that a lava has its own equilibrium constant of equation (4) because of an influence of coexisting $\mathrm{Na}$ and other ions (Table 1, Fig. 2) or coexisting minerals (Fig. 1).

The other is the application of redox reaction relation of iron-containing minerals. Especially as a lava mostly contain olivine and pyroxene, I have discussed mainly about these minerals on the basis of equations (12)-(16) by means of thermodynamic method. If we take an available information of $\mathrm{Po}_{2}$ in a lava, it may attribute to know exact temperature of generation of a lava. 


\section{References}

BAAK, T. and HoRNyAK, E. J. (1961): The Iron-oxygen equilibrium in glass; Effect of platinum on the $\mathrm{Fe}^{+2} / \mathrm{Fe}^{+3}$ equilibrium. Jour. Amer. Cer. Soc., 44, (5), 541-544.

Bowen, N. L. and Schairer, J. F. (1936): The system $\mathrm{MgO}-\mathrm{FeO}-\mathrm{SiO}_{2}$. Amer. Jour. Sci., 29, 185-200.

Coughuin, J. P. (1954): Contributions to the data of theoretical metallurgy, XII Heats and free energies of formation of inorganic oxides. U.S. Bur. Mines, Bull., $542,1-235$.

FudALI, R. F. (1965) : Oxygen fugacity of basaltic and andesitic magmas. Geochem. Cosmochem. Acta, 29, 1063-1075.

KELLEY, K. K. (1960) : Contributions to the data on theoretical metallurgy, XIII high temperature heat content, heat capacity and entropy data for the elements and inorganic compounds. U.S. Bur. Mines, Bull., 584, 1-232.

KENNEDY, G. C. (1948): Equilibrium between volatiles and iron oxides in igneous rocks. Amer. Jour. Sci., 246, 529-549.

- (1955): Some aspects of the roles of water in igneous rocks. Geol. Soc. Amer. Special paper, 62, 489-533.

KIRIYAMA, R. (1965): Electric polarization of ion in mineral and rock. Jour. Min. Soc. Japan, Special paper, 6, 78-90.

Kuno, H. (1950) : Petrology of Hakone volcano and the adjacent areas, Japan. Bull. Geol. Soc. Amer., 61, 957-1020.

(1954): Volcanoes and volcanic rocks (in Japanese). Iwanami Shoten, 1-255. (1965) : Some problems on calc-alkali rock series (in Japanese). Jour., Jap. Assoc., Min. Petr. \& Econ. Geol., 53, 131-142.

Muan, A. (1959): Stability relations among some manganese minerals. Amer. Min., 44, 946-960.

MuAN, A. and OSBorn, E. F. (1956): Phases equilibrium at liquidus temperature in the system $\mathrm{MgO}-\mathrm{FeO}-\mathrm{Fe}_{2} \mathrm{O}_{3}-\mathrm{SiO}_{2}$. Jour. Amer. Cer. Soc., 39, 121-140.

Osborn, E. J. (1959): Role of oxygen pressure in the crystallization and differentiation of basaltic magma. Amer. Jour. Sci., 257, 609-647.

(1962) : Reaction series for subalkaline igneous rock based on different oxygen pressure conditions. Amer. Min., 47, 211-226.

Shinno, I. (1966): Petrological studies of Kirishima volcanoes (in Japanese). Jour., Jap. Assoc., Min. Petr. \& Econ. Geol., 56, 56-74.

TANeda, S. (1943): Petrographic notes on the volcanic rocks from Haruna, Central Japan IV. Mem. Fac. Sci., Kyushu Univ., [D], 2, 15-96.

(1943): Occurrence of olivine at the peripheral zone of hypersthene phenocryst. Proc. Imp. Acad., 19, 31-36.

(1947): Petrological studies on the volcanic rocks from Japan with special reference to the "hornblendeandesite". Mem. Fac. Sci., Kyushu Univ., [D], 17, $311-330$.

Yoder, H. S. and TiLley, C. E. (1963) : Origin of basalt magma; An experiment study of natural and synthetic rock system. Jour. Petr., 3, 346-521.

YAGI, K. (1966): Progress in experimental petrology and astrogeology (Special address, in Japanese). Jour. Assoc. Min. Petr. \& Econ. Geol., 55, 5, 185-200. 